In a brief review such as this, it is not possible to refer to the many stages of development in the various types of discharge lamps-the low-pressure sodium lamp with hot cathode, the low-, medium- and high-pressure mercury lamps, or to mention more than briefly the $5 \mathrm{~kW}$. high-pressure water-cooled xenon are now being shown to the public for the first time. Many of these developments are illustrated by exhibits and are described in greater detail with diagrams and photographs in the official handbook, "Darkness into Daylight", by W. T. O'Dea, which has been published in connexion with the exhibition (London : H.M. Stationery Office. 1s.).

The exhibition will remain open until September from 10 a.m. until 6 p.m. daily, and from 2.30 p.m. until 6 p.m. on Sundays; admission is free at all times.

\section{PLANKTONIC COPEPODS AND HYDROCORALS OF THE JOHN MURRAY EXPEDITION}

$\mathrm{C}$

YOLONEL SEYMOUR SEWELL'S account* of A a large collection of free-swimming copepods from the Indian Ocean is an important critical study and a most valuable contribution to our knowledge of copepods in general.

In a previous paper (Sewell, 1920-32), seventeen species of free-swimming planktonic copepods were recorded from the northern part of the Indian Ocean, which up to that time were not known from any region other than the Atlantic Ocean or the Atlantic section of the Antarctic. The present collection contains twenty-one other species that so far have not been recorded beyond the Atlantic Ocean. As the author remarks, such a comparatively large number of deep-sea species that are common to the Atlantic and the Indian Ocean, but are at present unknown from any other region, indicates that there either is or has been a close connexion between the two regions. He has suggested (Sewell, 1940) that the explanation is to be found in the trend of the deep currents of the present day. He promises to deal later with the geographical distribution.

Well over two hundred species are recorded, with notes and remarks on most of them which are interesting and instructive. The new family Megacalanidæ is formed to include Megacalanus, Bathy. calanus and Brachycalanus, all of which differ from the Calanidæ in several features and show a corresponding resemblance to the Centropagidæ.

Only one specimen of Calanus finmarchicus was found, a male, from the northern area of the Arabian Sea, 1,500-0 metres. It is rare in the Indian Ocean and it is suggested that its presence is explained by individuals being carried from the Atlantic Ocean round the Cape of Good Hope in the North Atlantic intermediate waters or the West Wind Drift, and then that they are caught up in the Sub-Polar Intermediate Current and so are carried northwards into the Arabian Sea.

Among the Sapphirinas it was found that Sapphirina iris was associated with the aggregated form of the salp Pegea confederata, some being inside. In this

- The Free-Swimming Planktonic Copepoda: Systematic Account. By Lieut.-Colonel R. B. Seymour Sewell. (The John Murray Expedition, 1933-34, Scientiflc Reports, Vol. 8, No. 1.) Pp. 304. (London British Museum (Natural History), 1947.) 308. genus there were numerous cutaneous glands, opening on both dorsal and ventral aspects of the body in special positions in the different species. It is tempting to regard these as luminous organs, but the author does not wish to express an opinion on this point.

There is a long list of copepods with parasites both from surface-living and deep-dwelling species. This includes twenty-one species infested with the dino. flagellate Blastodinium. Comparing these with Chatton's seventeen species from the Mediterranean infested with Blastodinium, it is found that six are common to both lists.

Dr. Hjalmar Broch has found three new species in the four hydrocorals brought home by the John Murray Expedition to the Indian Ocean*. These include two new stylasters (S. (Eustylaster) ramosus and $S$. (Eustylaster) lonchitis), and one new Crypthelia (C. clausa), the fourth species being Crypthelia stenopoma Hickson and England. The two stylasters were from the Pemba Canal and the Crypthelia from the Maldives. It is interesting to note that in neither of these localities have Stylasteridæe been found before, and these reported localities of the John Murray Expedition are at the present day the most northerly localities of the Western Indian Ocean from which Stylasteridæ have as yet been found.

Another very interesting point is that whereas the two Stylaster species from the Pemba Canal have been collected in that zone of the bathymetrical region where the genus is known to be comparatively abundant in all seas, the localities of Crypthelia at the Maldives belong to the uppermost parts of its habitat, and its occurrence in these depths seems to be very scanty. The depth of 229 metres is the shallowest record of the genus, and Crypthelia stenopoma has hitherto only been taken in 1,300 metres or deeper in the Indo-Malayan Sea. Stylaster ramosus was abundant in two stations, its structure indicating that, like Crypthelia stenopoma and other Stylasteridæ, it is probably inhabited by commensal polychætes. The cirripede, Pyrgoma, is also com. monly found in it.

- Stylasteridm (Hydrocorals) of the John Murray Expedition to the Indian Ocean. By Dr. Hjalmar Broch. (The John Murray Expedition, 1933-34, Scientific Reports, Vol. 8, No. 2.) Pp. 305-361 +1 plate. (London : British Museum (Natural History), 1947.) 28. $6 d$.

\section{THE ELECTRICITY GRID IN GREAT BRITAIN}

$\mathrm{T}$ HE twentieth and last annual report of the Central Electricity Board has recently been published (Whitehead Morris, Ltd., 72-78 Fleet Street, London, E.C.4. 1s. net). Just short of attaining its majority, the Board loses its identity in the infant British Electricity Authority, this sturdy infant in. heriting the Grid system of some 150 generating stations, capable of an output of nearly 12 million kilowatts. Appropriately appearing at about the same time as this report is an interesting and informative paper dealing with the British grid system ("Load Dispatching and the British Grid System"A. R. Cooper, Institution of Electrical Engineers, March 18, 1948), a paper which is wider in scope than its title might suggest.

Mr. Cooper describes first the long-term planning associated with the extension of such a system; planning which, as the Central Electricity Board report makes clear, has had to yield to some extent 
to the stern demands of economic necessity, so that there is likely to be a serious shortage of plant for an indefinite number of years.

When assessing the need for future extensions, an estimate is required of the availability of existing plant, and some striking figures are given indicating that the technical advance in operating conditions has carried with it a general reduction in availability, so that breakdowns are more frequent on modern than on older plant. Leading sources of trouble are said to be turbine-blading failures due to vibration, and alternator rotor failures due to copper distortion, both of which are the subject of intensive research. Also responsible for reduced availability, as well as reduced output capacity, is the supply of unsuitable and low-grade fuels to the boiler plant, a war-time inheritance which persists in spite of the very great increase in the price of fuel.

Proceeding to the short-term planning associated with the daily operation of the Grid system, the paper reveals that the system was originally designed to operate as seven independent sections, and it was not until the load position in some areas had become very grave in 1939 that it was decided to try the experiment of operating the whole of the system in parallel. This operation was successful and has been continued ever since, though the possibility of sequential tripping of lines, accentuated by the existence of only two interconnectors between the north and south of Great Britain, has demanded careful consideration.

After an interesting description of the sequence of events in the planning of a single day's operation of this complex system, from the nerve centre at national control in constant communication with the seven area controls, the paper concludes with a brief review of future developments. The most significant changes foreseen are the introduction of the gas turbine for peak-load working, and of atomic energy for base-load generation. Here it is of interest to turn again to the report of the Central Electricity Board, which is able to cite the arrangements the Board has made for the installation of two $15,000 \mathrm{~kW}$. gas turbine sets, at Dunston and Stretford respectively; though the application of atomic energy remains a subject for study, and a hope for the future.

R. W. HAYWOOD

\section{MOSSES AS SOIL INDICATORS}

$I^{T}$

$\mathbf{T}$ is pleasing to see that the attention of foresters 1 is being directed to the mosses as indicators of soil conditions. H. Watson, forest officer instructor at the Benmore Forest School, Argyll, has produced an attractive booklet introducing this subject (Forestry Commission Booklet No. 1. Woodland Mosses. London: H.M. Stationery Office, 1947. $2 s$, net).

The brief introductory account of the life-history of a moss is followed by descriptions of twelve species likely to be encountered in afforestation areas. The descriptions are accompanied by 'turf' photographs to show the habit of growth in mass, and photographs of single shoots to illustrate the more detailed growth. form and include the salient features by which the species may be recognized in the field. There are also notes on the soil conditions favoured, especially as regards the degree of humus decomposition and soil acidity, and brief reference is made to the suitability or otherwise of the soil conditions indicated for afforestation purposes.
The mosses constitute a fascinating group of plants of which all too little is known. Many of them, after a little experience, can be recognized in the field by the naked eye or with the use of a hand lens, and type specimens may be kept dry in packets and soaked out again when required. Forest officers should be in a position to extend considerably our knowledge of the soil conditions indicated by the presence of particular moss species along the lines of the present booklet; and the recent production by Johnson and Sons, Ltd., of Hendon, N.W.4, of Universal and Comparator Test-papers for the measurement of $p H$ values to within $0.3 p H$, provides a very simple method for estimating the soil acidity with some degree of exactitude. Information of this kind would not only be of value to practical foresters, but would also extend our knowledge of this group of plants.

The British Bryological Society has recently asked its members to make observations on mosses with particular reference to times of production of capsules and reproductive organs in different carefully recorded localities and altitudes. The time of capsule production offers no difficulty, and in many cases the reproductive stage may be recognized by the opening of the antheridial cups, as illustrated in the booklet for Mnium hornum. It is to be hoped that foresters will be attracted by this aspect of ecology and that Forestry Commission Booklet No. 1 will be followed by others.

\section{FORTHCOMING EVENTS}

(Meeting marked with an asterisk * is open to the public)

Monday, May 24

LINNEAN SOotrTy of LONDON (at Burlington House, Piccadilly, London, W.1), at 4.30 p.m.- Anniversary Meeting.

ROXAL GROGRAPHTAL SOOIRTY (at Kensington Gore, London S.W.7), at 5.30 p.m.-Mr. E. W. Gilbert : "The Boundaries of Loca Government Areas".

Tuesday, May 25

ROYAL ANTHROPOLOGICAL INSTITUTE (at 21 Bedford Square London, W.C.1), at 5 p.m. -Dr. E. R. Leach : "Some Features of Social Structure among Sarawak Pagans".

EUGENIOS SOcrimY (at the Royal Society, Burlington House, Piccadilly, -London, W.1), at 5.30 p.m.-Prof. Brinley Thomas: "Migration and the British Commonwealth".*

Soomery OF INSTRUMRAT TECHNOLOGY (at the Royal Society of Tropical Medicine and Hygiene, Manson House, 26 Portland Place, London, W.1), at 6.30 p.m.-Annual General Meeting; Mr. J. K. Burkitt: "Proposed System in Instrumentation Symbols".

Wednesday, May 26

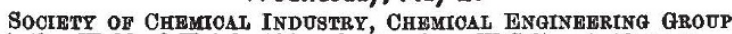
(at the Waldorf Hotel, Aldwych, London, W.C.2), at 12 noon.Annual General Meeting.

ROYAL MIOROSOOPICAL SOCTETY, SEOTION OF INDUSTRIAL MTOROsoopY (at B.M.A. House, Tavistock Square, London, W.C.1), at 6 p.m. -Dr. K. M. Greenland": "Principles of Interferenee Films used in Optical Instruments".

Thursday, May 27

ROYAL SOctETY (at Burlington House, Piccadilly, London, W.1), at 4.30 p.m. $\rightarrow$ Sir Edward Salisbury, F.R.S.: "The Royal Botanic Gardens, Kew".

ROYAL STATISTHOAL SOCTETY, RHEEAROH SBOTION (at the London School of Hygiene and Tropical Medicine, Keppel street, London, W.C.1), at 5.15 p.m.-Mr. D. G. Champernowne: "Sampling Theory pplied to Autoregressive Sequences".

ROYAL AERONAUTTCAL SOOIRTY (at the Institution of Civil Engineers, Great George Street, London, S.W.1), at 6 p.m.-Mr. A. Gouge : The 36th Wilbur Wright Memorial Lecture.

\section{Friday, May 28}

SOOIETY OF CHEMICAI INDUSTRY, FOOD GROUP (joint meeting with the ROYAL SANITARY INSTITUTR, at the Royal Hall, Ripon Road, Harrogate), at 10 a.m. -Discussion on "The Cleaning and Sterilizing

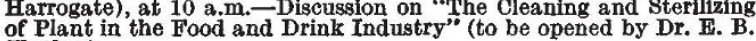
Hughes).

INSTIPOTR OP PHYSIOS, ELEOTRONIOS GROUP (joint meeting with the INDUSTRIAL SPFOTROSOOPIO GROUP, at 47 Belgrave Square, London, S.W.1) at 2.30 p.m.-Discussion on "The Application of ElectronMultipliers to spectroscopy". 